Jurnal Santiaji Pendidikan, Volume 11, Nomor 3, September 2021 ISSN 2087-9016, e-ISSN 2685-4694

\title{
STRATEGI PEMBELAJARAN KWL UNTUK MENINGKATKAN PRESTASI SISWA DALAM MEMPELARI TEORI SASTRA
}

\author{
I Gusti Agung Putri Wirastuti ${ }^{1}$, Anak Agung Istri Yudhi Pramawati² \\ Program Studi Pendidikan Bahasa Inggris, FKIP, Universitas Mahasaraswati Denpasar ${ }^{1,2}$ \\ Email:putri.wirastuti@unmas.ac.id
}

\begin{abstract}
ABSTRAK
Penelitian ini adalah penelitian tindakan kelas dengan menerapkan strategi KWL (Know, Want to know and Learn) yang bertujuan untuk meningkatkan kualitas pembelajaran dalam mempelajari teori sastra. Dalam penelitian ini, peneliti mengumpulkan data dari mahasiswa semester IV Program Studi Pendidikan Bahasa Inggris Mahasaraswati Denpasar yang mengambil mata kuliah Introduction to Literature. Strategi ini dapat membantu mahasiswa untuk memahami teori dan dalam KWL juga membantu dosen agar mahasiswa tetap termotivasi dan tertarik ketika mereka berpikir tentang apa yang ingin mereka ketahui dan apa yang telah mereka pelajari. Teknik pengumpulan data dilakukan melalui pre-test, post-test dan angket di akhir siklus. Selanjutnya peneliti menggunakan teknik tes berupa tes lisan untuk semua siklus. Target pencapaian atau ketuntasan belajar siswa adalah A sebesar 50\%, B sebesar $40 \%$, C sebesar 10\%, dan D 0\%. Dari hasil nilai rata-rata siswa terjadi peningkatan secara signifikan. Selain itu, hasil angket yang telah diberikan menunjukkan bahwa mahasiswa merespon positif penerapan strategi KWL dalam prestasi belajar mahasiswa. Hal ini dapat dilihat dari hasil angket bahwa lebih dari $90 \%$ memberikan respon yang baik bahwa strategi KWL dapat meningkatkan prestasi belajar mahasiswa dalam teori sastra.
\end{abstract}

Kata kunci: Strategi pembelajaran KWL, peningkatan prestasi belajar, teori studi literatur

\section{ABSTRACT}

This research is classroom action research by applying the KWL (Know, Want to know and Learn) strategy which aims to improve the quality of learning in studying literary theory. In this study, researchers collected data from fourth semester students of the Mahasaraswati Denpasar English Education Study Program who took the Introduction to Literature course. This strategy can help students to understand theory and in KWL can help other lecturers to keep students motivated and interested when they think about what they want to know and what they have learned. Data collection techniques were carried out through pre-test, post-test and a questionnaire at the end of the cycle. Furthermore, the researchers used a test technique in the form of an oral test for all cycles. Target achievement or completeness of student learning is A by 50\%, B by 40\%, C by 10\%, and D 0\%. From the results of the average value of students there was a significant increase. In addition, the results of the questionnaire that have been given indicate that students respond positively to the application of the KWL strategy in student achievement. It can be seen from the results of the questionnaire that more than $90 \%$ gave a good response that the KWL strategy can improve student achievement in literary theory.

Keywords: KWL learning strategy, increasing students' achievement, study literature theory

\section{PENDAHULUAN}

Pengantar Studi Sastra atau Introduction to Literature dipelajari pada semester empat. Materi yang diberikan adalah memberikan pengetahuan tentang Sejarah Sastra Inggris dan Genre Sastra. Karya sastra itu sendiri berarti memusatkan perhatian pada hakikat "sastra" dan "teks", yang membahas tiga genre tekstual utama seperti puisi, prosa dan drama dalam bidang Pendidikan Bahasa Inggris. Ini juga memberikan gambaran tentang periode terpenting Sejarah Sastra Inggris dari zaman dulu hingga zaman modern.

Sastra dapat diartikan sebagai tulisan imajinatif dalam arti fiksi atau tulisan yang 
tidak benar secara harfiah, tetapi beberapa karya tulis ditulis berdasarkan kisah nyata dan disebut non-fiksi, Eagleton (2008:2). Sastra adalah sesuatu yang mencerminkan kehidupan dalam masyarakat, sehingga membuat kita berpikir tentang kehidupan seperti yang kita alami sendiri dan masyarakat di sekitar kita. Dengan mempelajari sastra, memungkinkan kita untuk menikmati bahasa dan keindahannya.

Sastra adalah seni menyusun tulisan. Tulisan-tulisan diterbitkan dalam gaya dan bentuk tertentu pada topik tertentu. Semua bentuk seni yang menggunakan bahasa baik dalam bentuk tulisan maupun lisan. Dalam fungsi ini, karya sastra digunakan untuk menghibur pembaca. Karya sastra dikonsumsi untuk kesenangan seseorang. Dengan prestasi belajar secara umum, siswa mampu meningkatkan penerapan teori dasar sastra dalam berbagai jenis karya sastra antara lain puisi, prosa, dan drama). Setelah mereka memahami teoriteori sastra, diharapkan mereka memiliki landasan dasar untuk kegiatan pembelajaran selanjutnya. Mahasiswa mampu menganalisis dan mengklasifikasikan genre sastra serta menerapkan teori-teori sastra yang telah dipelajari mahasiswa sebelumnya.

Penelitian ini bertujuan untuk mencapai dan melihat bagaimana mahasiswa secara sederhana dapat menerapkan berbagai teori sastra yang telah dipelajarinya dalam menganalisis karya sastra. Prestasi ini seharusnya mendorong siswa untuk mengeksplorasi tentang berbagai jenis teori sastra untuk diterapkan dalam karya sastra. Metode dan gaya teori yang tercermin dalam mata kuliah teori sastra meminimalkan kontribusi mahasiswa sebagai mahasiswa dalam proses belajar mengajar sehingga kecenderungan belajar menjadi satu arah dengan fokus dominan pada dosen. Dari hasil angket yang disebar di awal penelitian, dapat diketahui bahwa motivasi siswa dalam mempelajari teori sastra masih kurang. Akibatnya proses belajar mengajar cenderung monoton dan tipe menghafal sehingga siswa cepat bosan.

Untuk mendapatkan hasil yang memuaskan, peneliti perlu mengadakan diskusi yang menghasilkan refleksi tentang perlunya penelitian tindakan kelas dengan menerapkan model pembelajaran kooperatif sehingga dapat meningkatkan hasil belajar siswa khususnya dalam bidang sastra. Menurut Slavin (2005:4) menyatakan bahwa pembelajaran kooperatif dapat merujuk pada berbagai metode pengajaran dimana siswa dapat bekerja dalam kelompok-kelompok kecil untuk saling membantu dalam mempelajari materi pelajaran. Untuk mendapatkan hasil yang maksimal seperti yang dikemukakan oleh Lie, (2005), ada lima unsur model pembelajaran kooperatif mutual yang harus dimiliki dalam mencapai hasil yang maksimal dalam pembelajaran kooperatif, yaitu: (a) saling ketergantungan positif, (b) tanggung jawab individu, (c) tatap muka, (d) komunikasi antar anggota, dan (e) evaluasi proses kelompok.

Salah satu teknik yang digunakan peneliti yang sangat cocok untuk meningkatkan hasil belajar sastra adalah KWL. Strategi KWL digunakan sebagai penyerapan struktur khusus yang dirancang untuk mempengaruhi pola interaksi siswa dan bertujuan untuk meningkatkan pembelajaran akademik mereka. Dengan strategi teknik KWL, mahasiswa diharapkan mampu memahami isi bacaan dan keluasan informasi yang diberikan oleh dosen. KWL juga membantu dosen untuk membuat mahasiswa tetap tertarik dengan pelajaran yang kita ajarkan ketika mereka memikirkan apa yang ingin mereka ketahui 
dan apa yang telah mereka pelajari. Ada beberapa manfaat KWL, seperti: membangun pengetahuan yang benar, mengembangkan orientasi dalam membaca, membantu siswa menjadi pembaca yang aktif dan kritis.

KWL merupakan kegiatan yang unik karena menarik minat siswa dalam melakukan proses membaca. Sebelum mereka membaca dan setelah mereka membaca, mereka dapat berbagi pengetahuan tentang topik yang telah mereka ketahui. Siswa dapat memperoleh ide-ide penting baru setelah membaca teks. Selain itu, siswa dapat memperoleh informasi baru setelah membaca teks. Dalam penelitian ini, strategi KWL melibatkan membuat siswa mengajukan tiga pertanyaan di awal dan mencatat catatan saat mereka mulai atau belajar atau membaca tentang suatu topik. Selain itu, KWL dapat digunakan oleh siswa secara individu maupun berpasangan dan kelompok kecil.

KWL adalah salah satu strategi pengajaran yang memiliki langkah-langkah sederhana dalam mengajar pemahaman membaca teks deskriptif. Selanjutnya, KWL merupakan strategi yang peneliti terapkan dalam penelitian ini pada mahasiswa semester IV Program Studi Bahasa Inggris di Mahasarswati Denpasar dalam mempelajari Teori Sastra Inggris. Strategi ini dapat membuat siswa memahami teks, dan mereka bisa menjadi pemahaman yang lebih baik dalam teori sastra. Ini adalah cara langsung untuk membuat topik atau konsep baru yang relevan dengan peserta didik berdasarkan pengetahuan mereka sebelumnya. Arends dan Kilcher (2010:146) menyatakan bahwa KWL melibatkan siswa dalam mengakses pengetahuan awal dan pertanyaan dan tujuan pembelajaran pertanian sebelum segmen instruksional, dan kemudian merefleksikan apa yang telah dipelajari setelah instruksi. Oleh karena itu, dapat membantu siswa dan guru untuk mengungkap miskoneksi dan konsep untuk pembelajaran sebelumnya.

Berdasarkan pernyataan Westwood (2001:60) menyatakan KWL dapat mengaktifkan pengetahuan awal siswa, pada kolom $\mathrm{K}$ siswa dan dosen/guru bersama-sama melakukan brainstorming dan menuliskan semua yang mereka ketahui tentang topik diberikan. Pada kolom W, siswa menghasilkan beberapa pertanyaan atau masalah yang mereka harap dapat dijawab pada teks (memprediksi, menanya, dan mencari informasi). Kolom L, siswa secara mandiri atau membagi aktivitasnya secara bersama-sama, siswa menulis ide dan ringkasan dari hal-hal utama yang telah mereka pelajari dari teks (merenungkan, mengkonsolidasikan, mengevaluasi, dan meringkas). Penggunaan strategi KWL merupakan salah satu strategi membaca secara aktif, yakni mempersiapkan siswa untuk membuat prediksi tentang apa yang akan mereka baca, serta melibatkan mereka dengan siswa, setiap siswa dan guru dari isi topik (Hassard, 2011:77). Untuk mengektifkan strategi KWL, membaca merupakan salah satu keterampilan yang harus dikuasai oleh siswa untuk memahami dan mengerti suatu bacaan. Mereka perlu diperkenalkan dengan sebanyak mungkin bahan bacaan seperti novel, koran maupun bacaan lainnya yang mereka suka yang bermanfaat untuk membantu mereka memperoleh banyak informasi dan pengetahuan melalui bahasa. Bacaan yang baik akan membuat pembaca bisa mendapatkan banyak tentang pengetahuan, informasi, kesenangan, atau bahkan dapat memecahkan suatu masalah. Selain itu 
Jurnal Santiaji Pendidikan, Volume 11, Nomor 3, September 2021 ISSN 2087-9016, e-ISSN 2685-4694

dengan membaca dapat membantu pembaca untuk menerima informasi yang disampaikan oleh penulis dalam bentuk teks.

\section{METODE PENELITIAN}

Dalam penelitian ini, peneliti memerlukan populasi dan sampel untuk mengambil data. Populasi dari penelitian ini yaitu mahasiswa Program Studi Bahasa Inggris Universitas Mahasaraswati Denpasar. Sampel dalam penelitian ini adalah mahasiswa semester IV kelas B yang sedang mengambil mata kuliah Introduction to Literature. Mahasiswa semester IV yang berjumlah 30 mahasiswa dipilih sebagai subjek penelitian berdasarkan hasil observasi yang hasilnya menunjukkan bahwa kurangnya motivasi mahasiswa dalam mempelajari teori sastra, terutama dalam bahan bacaan. Dengan menggunakan Strategi Pembelajaran KWL akan dapat membantu mahasiswa dalam memperoleh banyak pengetahuan dan informasi melalui bahasa. Pembaca bisa mendapatkan banyak pengetahuan, informasi, kesenangan, atau bahkan solusi masalah.

Penelitian tindakan kelas digunakan dalam penelitian ini. Desain penelitian tindakan kelas ini berkaitan dengan peningkatan prestasi belajar siswa mengenai teori sastra melalui Strategi KWL. Menurut Cohen dkk. (2005:227) menyatakan bahwa penelitian tindakan merupakan bentuk penyelidikan refleksi diri secara kolektif yang dilakukan oleh peserta dalam situasi sosial untuk meningkatkan rasionalitas dan keadilan praktik sosial atau pendidikan mereka sendiri, serta pemahaman mereka tentang praktik dan situasi tersebut di mana praktikpraktik ini dilakukan. Pendekatan ini dilaksanakan dalam bentuk penelitian tindakan kelompok yang akan dicapai melalui tindakan anggota kelompok yang diperiksa secara kritis.

Menurut Dawson (2007:16-17), dalam penelitian tindakan, peneliti bekerja sama dengan sekelompok orang untuk meningkatkan siswa dalam hal-hal tertentu. Dalam hal ini, peneliti bekerja dengan mereka dan bertindak sebagai fasilitator. Selain itu, keterampilan manajemen kelompok dan pemahaman yang baik tentang keberagaman kelompok merupakan keterampilan penting yang harus diperoleh peneliti. Jenis penelitian ini banyak digunakan di berbagai bidang termasuk pendidikan. Ferrance (2000:1), juga menyatakan bahwa penelitian tindakan kelas merupakan suatu proses di mana peserta dapat paraktik untuk memeriksa pendidikan mereka sendiri secara sistematis dan dengan hati-hati, dengan menggunakan strategi penelitian.

Pengumpulan data merupakan langkah penting dalam melakukan penelitian untuk menjawab masalah yang muncul. Peneliti menggunakan dua jenis instrumen dalam mengumpulkan data dari mahasiswa semester empat dalam penelitian tindakan kelas ini. Pertama peneliti mengadakan tes (pre-test dan post-test) dan angket. Hasil pre-test menunjukkan kemampuan mahasiswa yang sudah ada sebelum mereka mempelajari teori sastra dan sebelum penerapan strategi. Post-test menunjukkan hasil strategi atas pembelajaran mata pelajaran. Untuk mengetahui peningkatan belajar mata pelajaran mahasiswa, dapat dilihat dari hasil post-test dibandingkan dengan hasil pre-test. Tindakan ini dapat dikatakan efektif dalam meningkatkan prestasi belajar mata pelajaran teori sastra, jika nilai rata-rata post-test lebih tinggi dari nilai rata-rata pre-test.

Teknik yang digunakan dalam 
menganalisis data adalah statistik deskriptif, frekuensi hitung, dan persentase yang bertujuan untuk mengetahui sejauh mana kemajuan prestasi belajar siswa dalam teori sastra. Data akan disesuaikan dalam kategori dengan persentase yang ada. Rumus yang akan digunakan dalam pengolahan data, sebagai berikut:

$$
\mathrm{M}=\frac{\sum \mathrm{x}}{\mathrm{N}}
$$

$\mathrm{M}=$ nilai rata-rata prestasi belajar teori sastra

$\Sigma \mathrm{X}=$ jumlah nilai siswa

$\mathrm{N}=$ jumlah semua mata pelajaran

Setelah melakukan penelitian, angket diberikan pada akhir siklus untuk mengetahui respon siswa setelah menerapkan strategi KWL. Untuk mengetahui motivasi mahasiswa dalam belajar teori sastra, dan memudahkan mereka untuk menjawab pernyataan dalam kuesioner, peneliti menyebarkan sepuluh pernyataan yang ditulis dalam Bahasa Indonesia. Selanjutnya hasil kuesioner dianalisis dengan menggunakan skala penilaian 5 sampai 1. Skala tanggapan subjek angket sangat setuju (Sangat Setuju/SS) skor 5, setuju (Setuju/S) skor 4; bimbang (Ragu-ragu/RR) skor 3, tidak setuju (Tidak setuju/TS) skor 3 dan sangat tidak setuju (Sangat Tidak Setuju) skor 1.

\section{HASIL DAN DISKUSI}

Hasil dari data penelitian ini dikumpulkan dari kegiatan penelitian tindakan dan dianalisis. Penelitian ini berfokus pada analisis data yang terkumpul. Data yang dikumpulkan dari proses belajar mengajar dan evaluasi. Fungsi analisis data adalah untuk mengukur prestasi belajar siswa dalam teori sastra dapat ditingkatkan dengan menerapkan strategi pembelajaran KWL. Kemungkinan penelitian ini merupakan pembahasan utama dari penelitian yang dilakukan. Penelitian ini menunjukkan temuan dari data yang dikumpulkan peneliti dari awal sampai akhir penelitian. Temuan dari hasil ini terdiri dari hasil siklus I dan siklus II. Kedua siklus tersebut merupakan perlakuan penerapan strategi KWL untuk mencapai prestasi belajar mata pelajaran teori sastra melalui KWL. Penelitian menggunakan empat kegiatan setisp siklus yaitu; Perencanaan, tindakan, observasi dan refleksi. Dalam memperoleh data instrument, peneliti menggunakan tes konstruksi, rubrik penilaian dan kuesioner.

Penerapan strategi KWL dalam kelas, dapat menunjukkan kemajuan mahasiswa perlahan tapi pasti. Dalam penerapan strategi KWL, siswa dapat memprediksi ide dan jawaban mereka, rasa ingin tahu tentang topik yang diberikan, mereka menulis ide-ide dari materi yang diberikan peneliti dalam grafik KWL dan menyebutkannya, mereka juga menemukan ide utama, detail pendukung, referensi, dan kata-kata sulit. Dalam menemukan ide pokok, siswa membaca kalimat pertama atau terakhir dari teori. Siswa dengan cepat mencari beberapa informasi tertentu untuk menemukan detail-detail pendukung. Siswa juga dapat mencari referensi yang mengacu pada kalimat sebelumnya. Jika menemukan kata-kata sulit, siswa dapat langsung merujuk pada teks.

\section{Pra-Siklus}

Pre-test dilaksanakan untuk mahasiswa semester IV kelas B untuk menjawab tes awal untuk mengetahui pengetahuan awal mahasiswa terhadap teori sastra sebelum strategi KWL diterapkan. Hasil dari pre-test menunjukkan hasil yang kurang memuaskan tentang teori sastra, artinya pengetahuan mahasiswa masih belum sesuai dengan target. Begitu juga dengan 
hasil kuesioner yang masih rendah sebelum KWL dilaksanakan. Presentase yang rendah dari hasil awal tes mahasiswa, juga terlihat dari hasil tes lisan pada pra siklus. Tes lisan peneliti menanyakan dasar teori sastra. Hasilnya dari 30 mahasiswa hanya 6 (20\%) mahasiswa yang mendapatkan nilai B, 14 (47\%) mahasiswa mendapatkan nilai C dan 10 (33\%) mahasiswa mendapatkan nilai D. Hal ini menunjukkan bahwa target pencapaian mahasiswa dalam teori sastra belum tercapai.

\section{Siklus I}

Berdasarkan hasil pre test, maka siklus I dilaksanakan. Pada awal siklus 1 dilaksanakan Langkah penting, yaitu tindakan perencanaan dimana diharapkan dapat meningkatkan hasil prestasi mahasiswa. Pada siklus ini peneliti menerapkan instrument berupa materi yang sesuai. Hasil belajar pada siklus I peneliti menggunakan metode konvensional untuk mengetahui ketercapaian dalam teori sastra sebelum menerapkan strategi KWL. Selama proses belajar mengajar yang telah berlangsung, beberapa pelajaran kurang fokus pada materi, sehingga mahasiswa merasa bosan karena peneliti belum menerapkan strategi pembelajaran. Setelah materi pada siklus I selesai diperoleh hasil, dari 30 mahasiswa terdapat 8 mahasiswa (26\%) yang mendapatkan nilai A. 12 mahasiswa lainnya $(40 \%)$ mendapatkan nilai B. Sisanya 5 mahasiswa (17\%) mendapatkan nilai A. Nilai $C$ dan untuk nilai $D$ sebanyak 5 mahasiswa (17\%). Target pencapaian atau ketuntasan belajar adalah A sebesar $50 \%$, B sebesar $40 \%$, C sebesar $10 \%$, dan D $0 \%$.

Hasil data di atas menunjukkan bahwa target pencapaian mahasiswa semester IV kelas B belum mecapai target. Maka dari itu penelitian ini harus dilanjutkan ke siklus selanjutnya yaitu siklus II dengan menerapkan strategi pembelajaran KWL. Dengan digunakannya strategi pembelajaran yang tepat diharapkan hasilnya pun dapat meningkatkan hasil prestasi mahasiswa.

\section{Siklus II}

Pada siklus II, di perencanaan peneliti merevisi materi pelajaran sebelumnya untuk mencapai hasil sesuai harapan. Persiapan dalam proses belajar mengajar seperti perangkat pembelajaran dan kuesioner juga dipersiapkan. Slain itu peneliti juga menyiapkan materi mata pelajaran dengan metode strategi KWL (Know , Want to Know and Learn). Di kolom K, peneliti memberikan siswa brainstorming dengan berbagi topik dan daftar ide-ide dan rincian yang telah mereka ketahui tentang topik tersebut. Di kolom $\mathrm{W}$, siswa meninjau kembali topik dan mempertimbangkan apa yang masih ingin mereka ketahui. Di kolom L, siswa menambahkan rincian tentang apa yang telah mereka pelajari dalam teori sastra. Dengan menggunakan strategi KWL, mahasiswa harus mengisi kolom KWL sehingga mahasiswa dapat mengikuti mata kuliah secara serius dan aktif.

Hasil pengaplikasian strategi pembelajaran KWL pada siklus II terlihat adanya peningkatan prestasi belajar dalam teori sastra. Dari 30 mahasiswa, sebanyak 15 mahasiswa (50\%) yang mendapatkan nilai $\mathrm{A}$, yang mendapat nilai $\mathrm{B}$ ada 12 mahasiswa (40\%). Sisanya yng mendapat C sebanyak 3 orang (10\%) dan kelas D sebanyak 0 mahasiswa (0\%). Hasil siklus II menunjukkan target pencapaian dari penerapan KWL sudah melebihi target dalam mata kuliah Introduction to 
Jurnal Santiaji Pendidikan, Volume 11, Nomor 3, September 2021 ISSN 2087-9016, e-ISSN 2685-4694

Literature dalam meningkatkan pencapaian hasil belajar mahasiswa. Begitu juga terlihat dari hasil akhir kuesioner yang telah disebarkan, menunjukkan hasil lebih dari $90 \%$ sangat senang dan setuju akan efektifitas dari strategi pembelajaran KWL untuk meningkatkan tingkat prestasi belajar mahasiswa khususnya dalam mempelajari teori sastra.

\section{HASIL DAN PEMBAHASAN}

Hasil dan pembahasan ini dimulai dari pra-siklus untuk penelitian tindakan kelas. Dari hasil pre-test yang sudah dilaksanakan, dari 30 mahasiswa hanya sedikit mahasiswa yang mengetahui tentang teori sastra. Karena mahasiswa yang dipakai sebagai sample adalah mahasiswa keguruan, mereka masih belum bisa menelaaj apa fungsi dari teori sastra, jenis-jenis karya sastra, macam-macam teori sastra dan bagaimana mengaplikasikan teori sastra dan karya sastra dalam dunia Pendidikan. Hasilnya tidak ada siswa yang mendapatkan nilai $\mathrm{A}$ dan hanya $20 \%$ mahasiswa yang mendapatkan nilai $\mathrm{B}$, terdapat $47 \%$ mahasiswa yang mendapatkan nilai $\mathrm{C}$ dan $33 \%$ mahasiswa mendapatkan nilai D. Hal ini menunjukkan bahwa prestasi belajar teori sastra masih rendah. Respon mahasiswa juga kurang motivasi dalam belajar teori sastra berdasarkan hasil angket pertama.

Peneliti melanjutkan ke siklus I, dimana peneliti menggunakan metode konvensional untuk mengetahui ketercapaian teori sastra sebelum menerapkan strategi pembelajaran KWL. Setelah materi pada siklus I selesai, diperoleh hasil $26 \%$ mahasiswa mendapatkan nilai A. $40 \%$ mahasiswa lainnya mendapatkan nilai $\mathrm{B}$, dan $17 \%$ mahasiswa mendapatkan nilai $\mathrm{C}$ selanjutnya ada $17 \%$ mahasiswa yang mendapatkan nilai D. Artinya pencapaian tersebut belum mencapai target.

Pada siklus II, peneliti merevisi rencana dan lebih menekankan pada analisis materi teori sastra, yang terdapat pada genre literature yaitu pada karya sastra seperti puisi, drama dan prosa. Dan mempersiapkan implementasi strategi pembelajaran KWL digunakan sebagai pedomannya. Hasil siklus II terdapat 50\% mahasiswa yang memperoleh nilai $\mathrm{A}$, nilai B sebesar $40 \%$ dicapai mahasiswa. Sisanya nilai C $10 \%$ mahasiswa dan tidak ada mahasiswa yang mendapatkan nilai $\mathrm{D}$. Dari Grafik 4.1 data menunjukkan dari pre-test dan post-test akhir dari siklus II, ada peningkatan yang signifikan pada pelaksanaan KWL.

Untuk tambahan data pendukung, di akhir siklus II peneliti menyebarkan kuesioner kepada mahasiswa untuk mengetahui perkembangan motivasi mereka dalam belajar. Hasil data kuesioner dikumpulkan untuk mengetahui persentase tanggapan mahasiswa terhadap strategi KWL. Hasil angket dianalisis dengan menggunakan skala penilaian 5 sampai 1 . Dari Grafik 4.2 menunjukkan secara jelas Sebagian besar mahasiswa menanggapi respon sangat baik terhadap penerapan strategi pembelajaran KWL. Tanggapan angket strategi KWL: ada 60\% tanggapan sangat setuju, 38\% tanggapan setuju, 2\% ragu-ragu dan tidak ada jawaban mahasiswa tidak setuju dan sangat tidak setuju. Artinya lebih dari 90\% mahasiswa setuju bahwa penerapan KWL dapat meningkatkan prestasi belajar teori sastra 
mahasiswa.

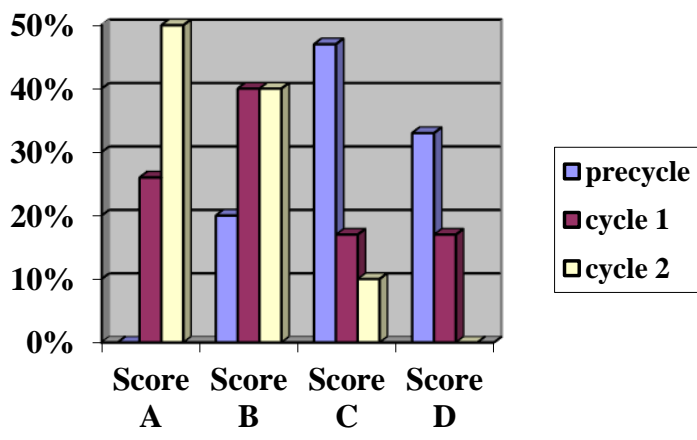

Gambar 1. Menggambarkan Kemajuan Prestasi Mata Pelajaran Teori Sastra melalui Strategi Pembelajaran KWL

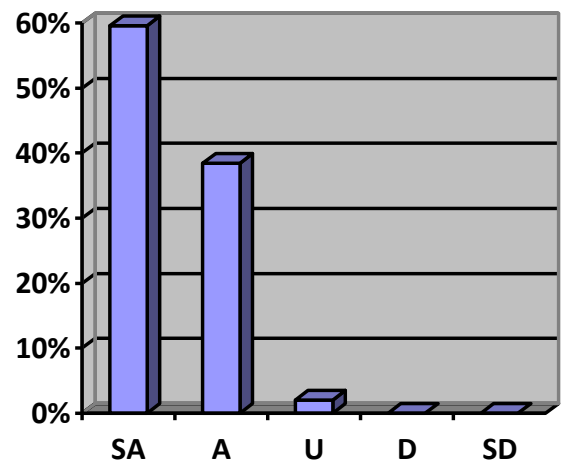

$\square$ Resposes

Gambar 2. Menggambarkan Kemajuan Prestasi Mata Pelajaran Teori Sastra melalui Strategi Pembelajaran KWL

\section{PENUTUP}

\section{Kesimpulan}

Strategi pembelajaran KWL bertujuan untuk memberikan motivasi dan meningkatkan keinginan mahasiswa untuk belajar teori sastra agar lebih menyenangkan dan berkualitas. Agar mahasiswa lebih berpartisipasi aktif dalam mengikuti pelajaran baik secara individu maupun berkelompok, maka perlu diberlakukan pembelajaran secara komprehensif. Sehingga pembelajaran teori sastra dapat mencapai kualitas yang lebih baik.
Berdasarkan permasalahan yang dihadapi mahasiswa, maka penelitian ini dilakukan untuk meningkatkan prestasi belajar pada mahasiswa semester IV kelas $\mathrm{B}$ teori sastra dengan menggunakan strategi pembelajaran KWL. Hasil pembelajaran pada pra siklus menunjukkan bahwa dari 30 siswa, hanya 6 (20\%) siswa yang mendapatkan nilai $\mathrm{B}$, ada $14(47 \%)$ siswa yang mendapatkan nilai $\mathrm{C}$ dan 10 (33\%) siswa yang mendapatkan nilai D. Siklus I Hasil penelitian menunjukkan, dari 30 siswa terdapat 8 siswa $(26 \%)$ yang mendapatkan nilai A. 12 siswa lainnya (40\%) mendapatkan nilai B. Sisanya 5 siswa (17\%) mendapatkan nilai $\mathrm{C}$ dan untuk nilai D sebanyak 5 siswa (17\%). Target peneliti dalam capaian prestasi mahasiswa adalah A sebesar 50\%, B sebesar $40 \%$, C sebesar 10\%, dan D $0 \%$. Peneliti melanjutkan penelitian ke siklus berikutnya. Dari hasil siklus II menunjukkan peningkatan prestasi dari 30 mahasiswa hanya 15 mahasiswa (50\%) yang mendapat nilai $\mathrm{A}$, ada 12 mahasiswa dengan nilai B (40\%). Selebihnya kelas C sebanyak 3 siswa (10\%) dan kelas D sebanyak 0 siswa (0\%). Selain itu, hal ini dengan jelas menunjukkan bahwa prestasi siswa dalam teori sastra dapat ditingkatkan dengan menerapkan strategi KWL. Maka, berdasarkan indikator keberhasilan capaian yang di targetkan, penelitian ini telah berhasil mencapai tujuan sehingga penelitian ini bisa dihentikan.

Data pendukung diambil dengan pemberian kuesioner. Hasil angket menunjukkan bahwa lebih dari $90 \%$ subjek setuju penerapan KWL dalam meningkatkan prestasi belajar teori sastra siswa. Hal ini jelas menunjukkan bahwa KWL dapat membuat mata pelajaran lebih aktif dalam kegiatan pembelajaran. Artinya, subjek sangat menerima 
Jurnal Santiaji Pendidikan, Volume 11, Nomor 3, September 2021 ISSN 2087-9016, e-ISSN 2685-4694

penerapan strategi KWL, dan sangat menikmati proses belajar-mengajar.

\section{Saran}

Saran pertama ditujukan pada mahasiswa semester IV Program Studi Pendidikan Bahasa Inggris Mahasaraswati Denpasar, disarankan mempelajari teoriteori sastra, seperti fungsi dan jenis-jenis karya sastra yang sesuai dengan, banyak bertanya bila ada materi yang belum dipahami. Partisipasi mereka juga sangat diperlukan selama mereka belajar tentang teori sastra agar lebih menarik dan menyenangkan. Saran kedua ditujukan pada peneliti berikutnya yang menggunakan strategi yang sama, strategi ini bisa diterapkan pada mata kuliah yang berbeda. Peneliti yang akan melakukan penelitian juga dapat memanfaatkan strategi ini dan memperbaiki kelemahankelemahan yang masih ditemukan dalam penelitian ini.

\section{DAFTAR PUSTAKA}

Arends, R. I. \& Kilcher, A. (2010). Teaching for Student Learning: Becoming an Accomplished Teacher. Oxon: Routledge.

Cohen, L., Manion, L., \& Marrison K. (2005). Research Method in Education. Fifth Edition. London and New York: Taylor \& Franchise

Dawson, C. (2007). Practical Research Methods: A User-Friendly Guide to Mastering Research Techniques and Projects. Oxford: Oxford University Press.

Eagleton, T. (2008). Literary Theory An Introduction: Blackwell Publishing Ltd.
Ferrance, E. (2000). Action Research. Providence: Brown University.

Hassard, J. (2011). Science as Inquiry 2nd Edition. United States of America: Good Year Books.

Klarer, M. (2004). An Introduction of Literary Studies. London: Routledge Taylor \& Francis Group.

Lie, A. (2005). Cooperating Learning: Mempraktikkan Cooperative Learning di ruang-ruang kelas (Vol. 7386). Jakarta: Gramedia.

Slavin, R. E. (2005). Cooperative learning Teori, Riset dan Praktik. Bandung: Nusamedia.

Westwood, P. (2001). Reading and Learning Difficulties. New York, Victoria: Australian Council for Educational Research Ltd. 